\title{
The Classification and Characterization of Chromobacteria from a Lowland River
}

\author{
By MAURICE O. MOSS, COLIN RYALL AND NIALL A. LOGAN \\ Department of Microbiology, University of Surrey, Guildford, Surrey GU2 $5 X H$
}

(Received 23 August 1977; revised 4 November 1977)

\begin{abstract}
A number of strains of chromobacteria which gave diffuse spreading colonies were isolated from the River Wey. Phenotypic data for the isolates indicated that these spreading chromobacteria had many characters of Chromobacterium but they could not be accommodated in either of the two recognized species $-C$. lividum and $C$. violaceum. Although closest to $C$. violaceum, the spreading chromobacteria represent a well-defined group of strains which we propose should be considered as a separate species and for which the specific name Chromobacterium fluviatile sp. nov. is suggested. The DNA of strains so far analysed has a mol \% GC of 50 to 52, adding further confirmation that they are distinct from other species of Chromobacterium.
\end{abstract}

\section{INTRODUCTION}

Chromobacteria are frequently isolated from fresh water and soil. During a study of the origin of these organisms in a river, a number of strains producing unusually thin, spreading, purple-pigmented colonies were observed. The colonies were like those formed by Cytophaga and related gliding bacteria. Purple- and violet-pigmented colonies have traditionally been associated with the genus Chromobacterium, especially if the pigment is violacein. However, the production of a particular metabolite, such as a pigment, may not be an adequate reason for defining a genus (Gauthier et al., 1975).

The genus Chromobacterium has had a confused and complex history. Sneath (1960), after an exhaustive study of pigmentation, flagellation, biochemical properties, morphology, serology and pathogenic properties, divided it into two groups: the mesophils, placed in C. violaceum, and the psychrophils, placed in $C$. lividum. Although recognizing that there may be some variability between isolates, isolates from soil and fresh water can usually be assigned to one of these two taxa using the small group of tests selected by Sneath (1966). The taxonomic relationships between Chromobacterium and other genera of bacteria are still uncertain. At one time the genus was placed in the family Rhizobiaceae (Conn, 1938; Conn \& Elrod, 1947) but numerous studies have subsequently made this untenable. On the basis of DNA homology, Heberlein, De Ley \& Tijtgat (1967) concluded that $C$. violaceum showed no closer affinity with Rhizobium and Agrobacterium than did Pseudomonas. Using an Adansonian analysis of the Rhizobiaceae, Moffett \& Colwell (1968) also concluded that Chromobacterium should be removed from the family. They also suggested that the two species $C$. violaceum and $C$. lividum might be considered as separate genera and transferred into the family Pseudomonadaceae. Sneath $(1960,1974)$ has pointed out that there are few serological cross-reactions between the two species, and a numerical taxonomic study by Snell \& Lapage (1973) indicated that there was a higher similarity index between $C$. violaceum and some strains of other genera than between $C$. violaceum and C. lividum. Marchal \& Lasseur-Charpiot (1970) have demonstrated some antigenic relationships between Chromobacterium violaceum and Serratia marcescens. On the other hand, Bernaerts \& De 
Ley (1971) have demonstrated that some strains of $C$. lividum can oxidize gluconate to 2,5dioxogluconate, via 2-oxogluconate, a reaction known previously only in Gluconobacter.

The objective of this study was to characterize the purple isolates from the River Wey and determine their relationship with the genus Chromobacterium as it is presently understood.

\section{METHODS}

Strains. Strains 1 to 76,78 to 93,159 to 165,180 to 187 and 189 to 191 were isolated from water samples taken from the River Wey. Strains 77 and 119 to 158 were isolated from soil samples taken from the banks of the river. Strains 94 to 118 and 188 were isolated from river sediments. Strains 166 to 172 were Chromobacterium violaceum: respectively, strains F91 (University of Surrey), NCTC 9371, 9372, 9373, 9374, 9376 and 9757 (neotype). Strains 173 and 174 were Chromobacterium lividum: respectively, strains F1308 (University of Surrey) and NCTC 9796 (neotype). Other strains were: 175, Acinetobacter anitratum NCTC 7364; 176, Pseudomonas aeruginosa F1802 (University of Surrey); 177, Bacillus subtilis NCTC 3610; 178, Enterobacter cloacae F1809 (University of Surrey); and 179, Paracoccus denitrificans NCIB 8944.

Isolation and maintenance of strains. Plates of quarter-strength nutrient agar ( $\left.\frac{1}{4} \mathrm{NA}\right)$ [prepared by adding $1.5 \%(\mathrm{w} / \mathrm{v})$ Davis agar to quarter-strength Oxoid nutrient broth (1 $\mathrm{x} N \mathrm{NB})]$, colistin/deoxycholate agar (CDA) and colistin/deoxycholate/cycloheximide agar (CDCA) described by Ryall \& Moss (1975) were used for routine counting of chromobacteria. Any purple colonies were picked off into $\frac{1}{4} \mathrm{NB}$ and incubated overnight at $25^{\circ} \mathrm{C}$ before streak inoculating on fresh plates of $\frac{1}{4} \mathrm{NA}$ to confirm their purity. Cultures in $\frac{1}{4} \mathrm{NB}$ were stored at $4{ }^{\circ} \mathrm{C}$ and subcultured every 6 months; strains obtained from culture collections were also maintained in $\frac{1}{4} \mathrm{NB}$ at $4{ }^{\circ} \mathrm{C}$ but were subcultured at fortnightly intervals.

Colonial and cell morphology. Bacteria were grown on $1 \mathrm{NA}$ at $25^{\circ} \mathrm{C}$ for $8 \mathrm{~d}$ and colonies were observed with a hand lens. The morphology, regularity and pigmentation of the colonies were observed and their texture was tested with a sterile needle. Motility was examined using a hanging drop preparation of bacteria grown in $\frac{1}{4} \mathrm{NB}$ for $18 \mathrm{~h}$ at $25^{\circ} \mathrm{C}$, and this material was also used for Gram-staining. Flagella staining was carried out on bacteria grown on a 1 NA slope for $18 \mathrm{~h}$ at $25^{\circ} \mathrm{C}$; the bacteria were gently washed off with sterile distilled water and stained using the formulation 'A' of Leifson's stain (Norris \& Swain, 1971).

Pigmentation. To encourage pigmentation, isolates were grown on potato/dextrose agar and on mannitol/ yeast extract agar (Cowan \& Steel, 1965) for 3 to $5 \mathrm{~d}$ at $25^{\circ} \mathrm{C}$. The rate, uniformity and intensity of pigment production were recorded. The solubility of the pigment in water, ethanol, diethyl ether and chloroform was tested by stirring a small portion of the culture with solvent on a white tile. The colour changes occurring following the addition of either $10 \%(\mathrm{v} / \mathrm{v}) \mathrm{H}_{2} \mathrm{SO}_{4}$ or $10 \%(\mathrm{w} / \mathrm{v}) \mathrm{NaOH}$ to a drop of an ethanolic solution of pigment in a test tube were recorded. Ultraviolet and visible spectra of filtered ethanolic solutions of the pigments were also determined.

Growth tests. The ability to grow at 4 and $37{ }^{\circ} \mathrm{C}$ was checked after incubation on $\frac{1}{4}$ NA slopes for $7 \mathrm{~d}$. Control cultures, and all other tests, were incubated at $25^{\circ} \mathrm{C}$.

Ability to grow on acetate was tested using a medium containing $\left(\mathrm{g} \mathrm{l}^{-1}\right): \mathrm{NaCl}(2 \cdot 5) ; \mathrm{MgSO}_{4} .7 \mathrm{H}_{2} \mathrm{O}(0 \cdot 2)$; $\left(\mathrm{NH}_{4}\right)_{2} \mathrm{HPO}_{4}(1 \cdot 0) ; \mathrm{K}_{2} \mathrm{HPO}_{4}(1 \cdot 0)$; sodium acetate, hydrated (2.0); Oxoid Ionagar no. $2(15 \cdot 0)$; adjusted to pH 6.8 before autoclaving. Plates were inoculated by spreading a small inoculum over a large area and incubated for $7 \mathrm{~d}$. Isolates showing growth were subcultured on to a second plate of acetate agar and only visible growth on this plate was recorded as positive.

Ability to grow on a medium containing four times the normal concentration of nutrient broth solidified with $1 \%(\mathrm{w} / \mathrm{v})$ Davis agar (4NA) and anaerobically on $\frac{1}{4} \mathrm{NA}$ were tested.

Biochemical tests. The production of $\mathrm{H}_{2} \mathrm{~S}, \mathrm{HCN}$, urease, phosphatase, amylase and catalase were tested using methods described in Cowan \& Steel (1965). Oxidase was tested using the modification of Kovacs' (1956) method described by Sivendra, Lo \& Lim (1975).

Both the $\mathrm{O} / \mathrm{F}$ test on glucose and the production of acid from carbohydrates and related compounds were examined using the basal medium of Hugh \& Leifson (1953) containing $1 \%(\mathrm{w} / \mathrm{v})$ substrate as suggested by Sneath (1974).

The ability to utilize malonate and citrate, to reduce nitrate, nitrite and methylene blue, to deaminate phenylalanine and to decarboxylate ornithine, arginine and lysine were examined using methods described by Cowan \& Steel (1965), as were the egg yolk reaction, methyl red and Voges-Proskauer tests, the method of O'Meara (1931) being used to detect acetoin in the last test.

The hydrolysis of aesculin and casein were examined using the methods of Sneath (1966). Two methods were used to study gelatin hydrolysis: (i) nutrient gelatin (Oxoid) was stab inoculated and examined for growth and liquefaction within $7 \mathrm{~d}$; and (ii) plates of gelatin agar were streak inoculated and incubated for $4 \mathrm{~d}$, and then growth was scraped away and the medium was flooded with acidified aqueous $\mathrm{HgCl}_{2}(10 \%$, $\mathrm{w} / \mathrm{v}$ ), clear zones indicating areas of gelatin hydrolysis. 
Haemolysis was studied using plates of Oxoid blood base agar containing 9 to $10 \%(\mathrm{v} / \mathrm{v})$ fresh citrated goat blood.

The ability to oxidize gluconate was examined using the medium of Shaw \& Clarke (1955), Benedict's reagent being used for the detection of reducing compounds produced.

Where relevant, control was exercised in the size of the inoculum used for setting up tests, and strains of bacteria known to give either positive or negative results were included in each test to assist interpretation.

Coding of test results. The results of the seven tests described by Sneath (1966) and of 32 other tests (see Table 3) were coded as binary data.

The results from a study of 10 strains $(162$ to 166,172 to $174,189,190)$ using 59 tests were coded in a quantitative manner, each character being scored as strongly positive (99), moderately positive (95), weakly positive (90), very weakly positive (85) or negative (01). Included with these results were those for simulated strains of $C$. violaceum and C. lividum which were constructed from the results given by Sneath $(1956 a, 1957$, 1974). Pseudomonas aeruginosa (NCTC 2000) and Serratia marcescens (NCTC 1377) were included for comparison, results being drawn from several sources (Sneath, 1957; Thornley, 1960; Sakazaki, 1974).

Analysis of results. The results obtained from our studies were analysed using two approaches: (i) principal components analysis (PCA) using a modified version of the programme written by Wahlstedt \& Davis (1968); (ii) cluster analysis using the Clustan package of Wishart (1969). Cluster analysis was carried out on a matrix of dissimilarity coefficients calculated using square Euclidean distances which, for binary data, gives the same result as Sneath's matching coefficient (Sokal \& Michener, 1958). Various clustering methods were employed, all of which gave essentially the same groupings. The most comprehensive dendrogram has been presented.

\section{RESULTS}

Although purple colonies were readily obtained from the water, bottom sediments and soils associated with the River Wey, especially during the winter months, the spreading types were very much less common and were only isolated during the summer months. All the purple colonies were Gram-negative, catalase-positive, motile rods. The purple pigments were non-diffusible, insoluble in chloroform and ether but readily soluble in ethanol. The ethanolic solution turned green with $\mathrm{H}_{2} \mathrm{SO}_{4}$ and red-brown with $\mathrm{NaOH}$ solution. These pigments from a range of isolates were identified as violacein by comparison of their absorption spectra with that reported by Johnson \& Beer (1971).

The chromobacteria isolated showed a considerable diversity in colony morphology, texture, shape and pigmentation but, despite this diversity, they formed a few distinct groups one of which contained the strains giving thinly spreading colonies. This spreading habit was retained even when isolates were subcultured on specially dried plates of agarbased media.

All the chromobacteria, except a very small number of the isolates and the culture collection group of $C$. violaceum, grew at $4{ }^{\circ} \mathrm{C}$. None but the strains of $C$. violaceum grew at $37{ }^{\circ} \mathrm{C}$. Indeed the majority of isolates gave results characteristic of $C$. lividum in many of the tests used. However the group of psychrophils with spreading colony morphology, described here as Chromobacterium fluviatile, showed a closer affinity with $C$. violaceum (Table 1 ). Some tests were variable amongst strains of each species; thus, whereas all strains of $C$. violaceum tested could grow on 4NA, only $20 \%$ of strains of $C$. fluviatile tested could do so, and whereas no strains of $C$. fluviatile tested could grow on acetate agar, over $50 \%$ of strains of $C$. violaceum could do so.

Microscopically, the spreading isolates frequently showed chains of bacteria and occasionally exhibited pleomorphism, there being slightly curved rods of up to five or even ten times the normal length. Sneath (1974) suggested that pairs and short chains only occurred occasionally in chromobacteria although Leifson (1956) found great variation in the degree of chain formation.

All isolates, including those of $C$. fluviatile, were motile in hanging drop preparations with both polar and lateral flagella. A polar flagellum was present in all bacteria but in most strains only about 1 to $5 \%$ of bacteria possessed lateral flagella and then usually only one (Fig. 1). The flagella pattern of the spreading strains, therefore, while not explaining 
Table 1. Major differential characters of species of Chromobacterium

Character

Growth at $4{ }^{\circ} \mathrm{C}$

Growth at $37^{\circ} \mathrm{C}$

Cyanide produced

Egg yolk reaction

Acid from trehalose

Acid from arabinose

Acid from xylose

Casein hydrolysis

Aesculin hydrolysis

Glucose fermented (O/F test)

Arginine decarboxylase

$\mathrm{Mol} \% \mathrm{GC}$
C. violaceum

C. lividum

C. fluviatile

* A weak reaction only observed under the colony.

$\begin{array}{ccc}- & + & + \\ + & - & - \\ + & - & - \\ + & - & + \\ + & - & + \\ - & + & - \\ - & + & - \\ + & - \text { or }(+) & + \\ - & + & - \\ \mathrm{F} & \text { O } & \text { F } \\ + & - & - \\ 63-68 & 65-72 & 50-52\end{array}$

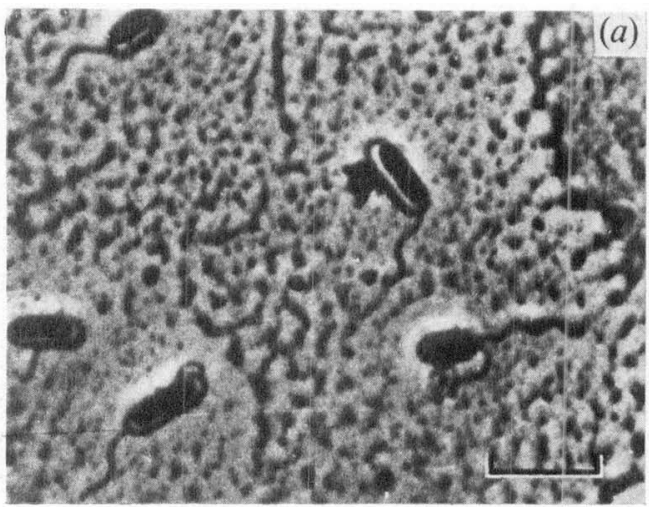

Fig. 1. Chromobacterium fluviatile stained for flagella using the method of Leifson:

(a) strain 162; (b) strain 165. Bar markers represent $5 \mu \mathrm{m}$.

their colonial characteristics, adds confirmation to their belonging to the genus Chromobacterium as currently understood (Leifson, 1956; Sneath, 1956b, 1960).

\section{Computer studies}

Principal components analysis. The programme used in the principal components analysis allowed the extraction of principal components from three different matrices, i.e. transformed distance, covariance and correlation. Figure 2 represents a map based on the analysis of the transformed distance matrix using the results of Sneath's seven tests (Table 2) on all isolates. The first two eigenvectors contain $89 \%$ of the total variance $(78 \%$ in eigenvector 1 and $11 \%$ in eigenvector 2) and the isolates form five major groups (A to E), three minor groups each containing two or three isolates and eight ungrouped strains. The seven tests were chosen to separate C. lividum (group A) from C. violaceum (group E). On the basis of these tests the majority of isolates (111) were identical with $C$. lividum, but a few anomalously either produced acid from trehalose (group B) or failed to produce acid from arabinose (group C).

The spreading isolates were all associated with group D with the exception of a single strain (no. 161) which produced acid from arabinose. Although group D is well separated from the other major groups a small number of strains gave anomalous results, with two or more of the seven tests producing a scatter of points on the map between the major groups.

In the principal components analysis of the results of 32 tests (Table 3 ) for all strains, analysis of the correlation matrix allowed the clearest interpretation. In this instance the 


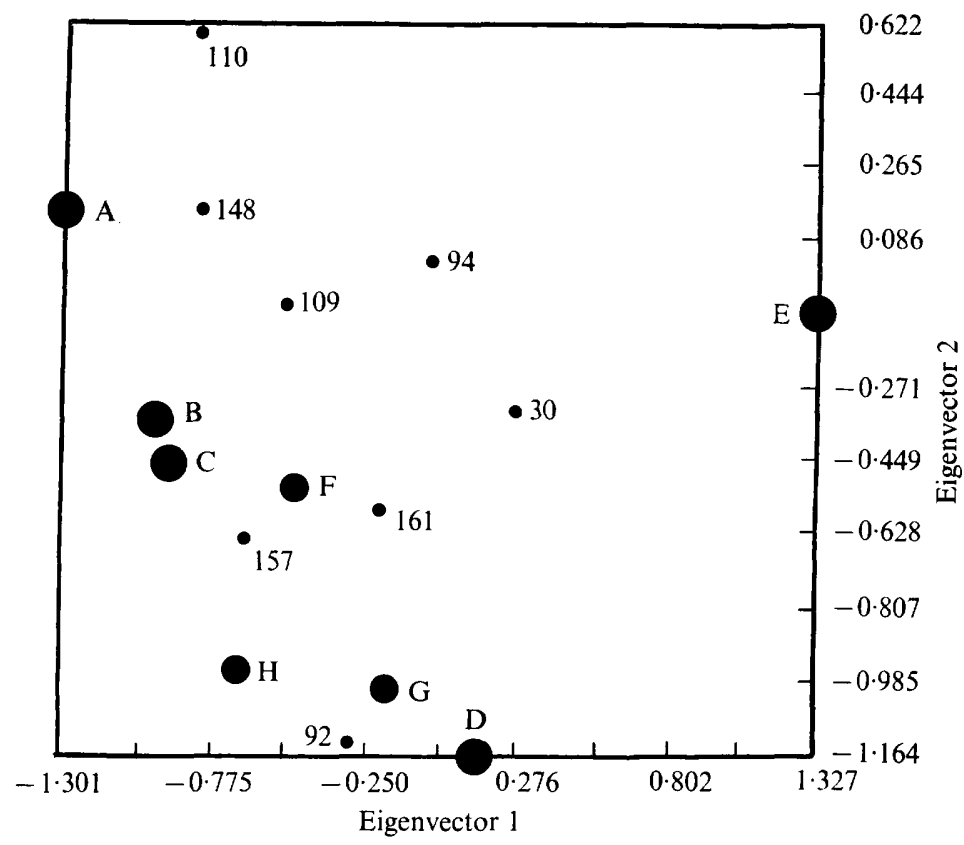

Fig. 2. Map based on principal components analysis of the transformed distance matrix of 186 strains of chromobacteria examined using the seven tests of Sneath. Cluster A, 111 strains; B, 8; C, 32; D, 12; E, 7; F, 2; G, 3; H, 3 strains.

Table 2. Results pattern for groups formed by principal components analysis (seven tests, see Fig. 2)

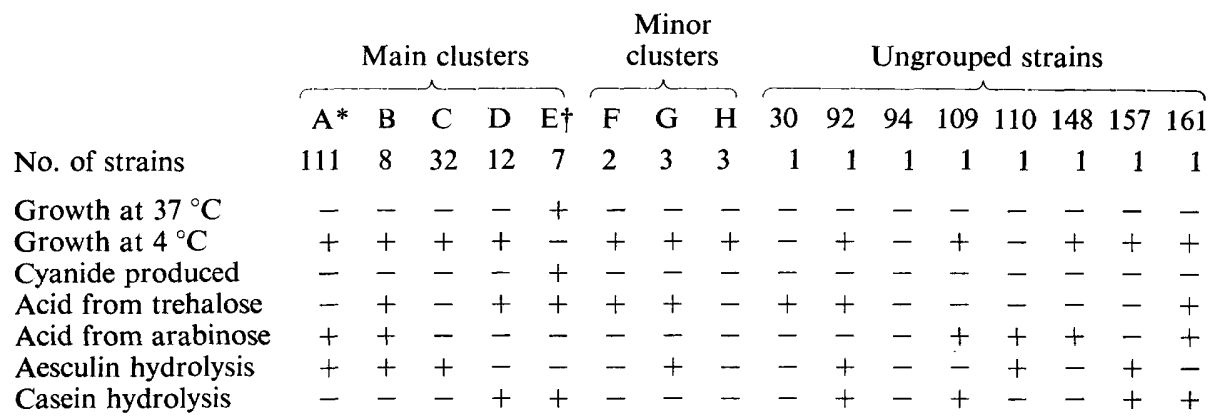

* Results typical of Chromobacterium lividum.

$\uparrow$ Results typical of Chromobacterium violaceum.

first five eigenvectors contained $55 \%$ of the variability (eigenvector $1,26.5 \%$; eigenvector 2 , $13.3 \%$ ) and the map based on the first two eigenvectors (Fig. 3) shows that the 186 isolates of chromobacteria could be grouped into five clusters, leaving only three isolates ungrouped. Such a grouping must be considered subjective (see Sneath, 1972) and clusters K (C. lividum), $\mathrm{L}$ and $\mathrm{M}$ (atypical $C$. lividum) may become a diffuse continuum if a sufficient number of strains could be studied. Once again the spreading isolates occupy a well-defined cluster (group $\mathrm{N}$ ) separated from both $C$. violaceum (group $\mathrm{O}$ ) and the clusters considered to contain C. lividum and its atypical forms. An analysis of the results obtained with these 32 tests is given in Table 3 and a concordance of these groupings with those based on the analysis of the results of the seven Sneath tests is shown in Table 4.

Cluster analysis. As well as the 32 tests shown in Table 3, a further nine tests which usually 


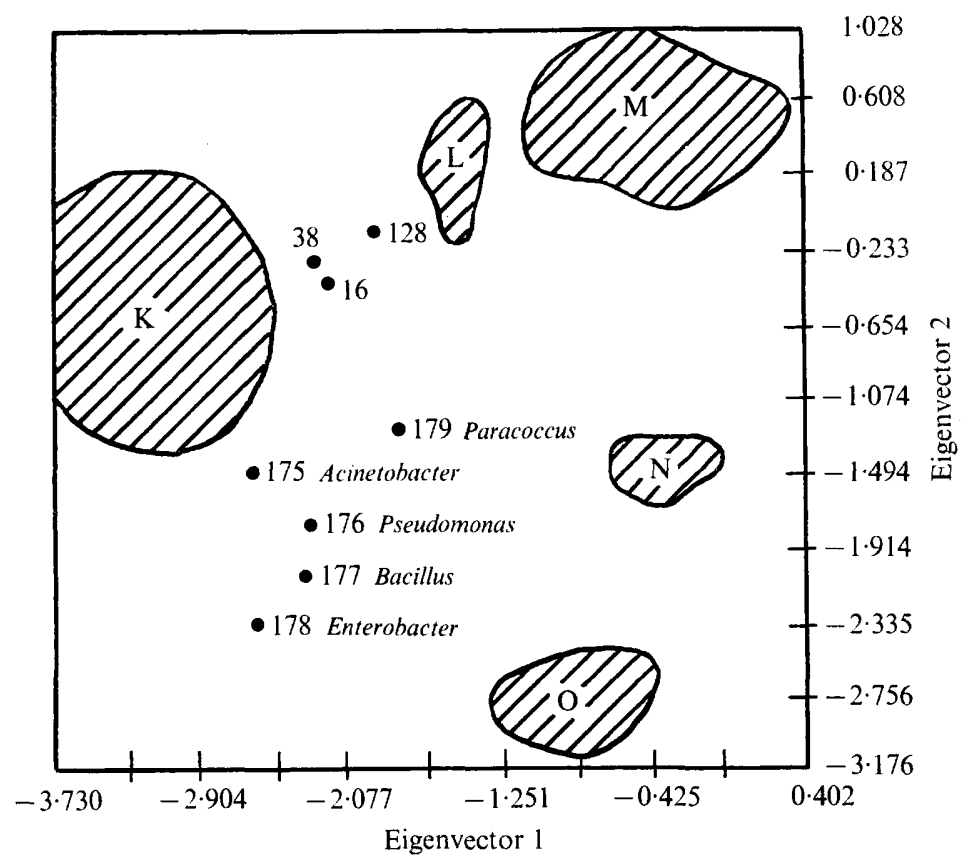

Fig. 3. Map based on principal components analysis of the correlation matrix of 186 strains of chromobacteria and five other strains examined using 32 tests. Cluster K, 139 strains; L, 11; $\mathrm{M}, 16 ; \mathrm{N}, 10 ; \mathrm{O}, 7$ strains.

gave results common to all isolates (Gram-stain - , motility + , round-ended rods + , violacein produced + , catalase + , citrate utilization + , methyl red - , Voges-Proskauer - , phenylalanine deamination -) were included in a cluster analysis. A dendrogram based on the McQuitty's similarity analysis was constructed. Clustering at the $77 \%$ similarity level gave five groups which are essentially identical with the clusters obtained using the principal components analysis (see Table 5).

Cluster I, which contained the neotype strain of $C$. lividum, also contained most of the isolates of this study and may be considered to represent this apparently variable species. Clusters II and III were clearly separated in the dendrogram, although the shape of the corresponding groups $\mathrm{L}$ and $\mathrm{M}$ in the map of the principal components analysis (Fig. 3) might be thought to indicate a continuous spectrum from the typical strains of $C$. lividum in group K. Clusters II and III probably encompass isolates once regarded as the separate species $C$. amethystinum (Breed, Murray \& Smith, 1957) and all the isolates grouped into these clusters do produce gelatinous colonies on agar media. The majority of isolates in cluster III do not produce acid from sugars or polyalcohols and many of them were isolated from the soil.

Cluster IV, which contained all the spreading isolates, showed a greater separation from the other psychrophilic strains (clusters I, II and III) than from the mesophilic strains (cluster V) of $C$. violaceum. These organisms are too well separated to be placed with the other psychrophils and yet they are readily distinguishable from $C$. violaceum.

Further study of the spreading strains. Isolates 162 to 165,189 and 190, together with culture collection strains of $C$. lividum $(173,174)$ and $C$. violaceum $(166,172)$, were re-examined using all but four of the tests described for the previous cluster analysis with the following additional observations: chains of more than two bacteria; length $>3 \mu \mathrm{m}$; lateral flagella present; polar flagella present; diffuse edges to colonies; pellicle formed in broth; pleomorphic forms present; fluorescein produced; prodigiosin produced; pyocyanin produced; arginine decarboxylase; gluconate oxidation; haemolysis of goat blood; $\mathrm{H}_{2} \mathrm{~S}$ production; 
Table 3. Results pattern for groups formed by principal components analysis (32 tests, see Fig. 3) expressed as a percentage of strains giving positive results

\begin{tabular}{|c|c|c|c|c|c|c|c|c|}
\hline \multirow[b]{2}{*}{ No. of strains } & \multicolumn{5}{|c|}{ PCA groups } & \multicolumn{3}{|c|}{ Ungrouped strains } \\
\hline & $\begin{array}{r}\text { K } \\
139\end{array}$ & $\begin{array}{c}\mathbf{L} \\
11\end{array}$ & $\begin{array}{l}M \\
16\end{array}$ & $\begin{array}{l}\mathrm{N} \\
10\end{array}$ & $\begin{array}{r}\mathrm{O} \\
7\end{array}$ & $\begin{array}{r}16 \\
1\end{array}$ & $\begin{array}{r}38 \\
1\end{array}$ & $\begin{array}{r}128 \\
1\end{array}$ \\
\hline Growth on acetate & 89 & 9 & 26 & 0 & 57 & - & + & - \\
\hline Growth on 4NA & 66 & 0 & 0 & 20 & 100 & + & + & - \\
\hline Pigment variability & 7 & 27 & 6 & 0 & 0 & - & - & - \\
\hline Colonies gelatinous & 33 & 100 & 100 & 0 & 0 & + & + & - \\
\hline Growth at $4^{\circ} \mathrm{C}$ & 100 & 100 & 81 & 100 & $\mathbf{0}$ & + & + & + \\
\hline Growth at $37^{\circ} \mathrm{C}$ & 0 & 0 & 0 & 0 & 100 & - & - & - \\
\hline Cyanide produced & 0 & $\mathbf{0}$ & 0 & 0 & 100 & - & - & - \\
\hline Casein hydrolysis & 0 & 0 & 38 & 100 & 100 & - & - & - \\
\hline Aesculin hydrolysis & 100 & 100 & 75 & 0 & 0 & + & + & + \\
\hline Anaerobic growth & 35 & 9 & 19 & 100 & 100 & + & - & - \\
\hline Nitrate reduced & 100 & 100 & 100 & 100 & 86 & + & + & + \\
\hline Nitrite reduced & 79 & 73 & 94 & 0 & 14 & + & + & + \\
\hline Gas from nitrate & 42 & 54 & 81 & 0 & 14 & - & - & + \\
\hline Glucose fermented (O/F test) & 0 & 0 & 0 & 100 & 100 & - & - & - \\
\hline Gelatin hydrolysis & 44 & 91 & 50 & 100 & 100 & + & + & + \\
\hline Starch hydrolysis & 1 & 91 & 19 & 10 & 0 & + & - & + \\
\hline Malonate utilization & 3 & 0 & 0 & 0 & 0 & - & - & - \\
\hline \multicolumn{9}{|l|}{ Acid from: } \\
\hline Arabinose & 78 & 64 & 26 & 10 & 0 & + & - & + \\
\hline Cellobiose & 100 & 100 & 31 & 30 & 86 & + & + & + \\
\hline Fructose & 100 & 64 & 6 & 100 & 100 & + & + & + \\
\hline Galactose & 100 & 100 & 13 & $80 *$ & 86 & + & + & + \\
\hline Glucose & 100 & 91 & 63 & 100 & 100 & + & + & + \\
\hline Glycerol & 96 & 0 & 0 & 30 & 100 & + & + & - \\
\hline Inositol & 86 & 9 & 6 & 0 & 43 & - & + & + \\
\hline Inulin & 48 & 9 & 6 & 0 & 0 & - & - & - \\
\hline Lactose & 17 & 55 & 19 & 0 & 100 & - & - & + \\
\hline Maltose & 100 & 64 & 69 & 100 & 86 & + & + & + \\
\hline Mannitol & 90 & 0 & 6 & 0 & 0 & - & - & - \\
\hline Mannose & 99 & 82 & 6 & 90 & 100 & + & - & + \\
\hline Sorbitol & 86 & 0 & 0 & 0 & 0 & - & - & - \\
\hline Sucrose & 89 & 82 & 6 & 10 & 43 & + & - & + \\
\hline Trehalose & 4 & 55 & 56 & 100 & 100 & - & - & + \\
\hline
\end{tabular}

* Subsequent studies have shown that most strains of $C$. fluviatile including the type strain are negative in this test, as are most strains of $C$. violaceum.

Table 4. Concordance of the number of strains common to the clusters formed by the principal components analysis of the 7 and 32 tests (see Figs 2 and 3)

PCA groupings using 32 tests

\begin{tabular}{lrrrrrrr}
$\begin{array}{l}\text { PCA groupings } \\
\text { using 7 tests }\end{array}$ & \multicolumn{1}{l}{} & $\mathrm{L}$ & $\mathrm{M}$ & $\mathrm{N}$ & $\mathrm{O}$ & $\begin{array}{c}\text { Ungrouped } \\
\text { strains }\end{array}$ & Total \\
A & 107 & 3 & 0 & 0 & 0 & 1 & 111 \\
B & 2 & 4 & 1 & 0 & 0 & 1 & 8 \\
C & 29 & 2 & 0 & 0 & 0 & 1 & 32 \\
D & 0 & 0 & 3 & 9 & 0 & 0 & 12 \\
E & 0 & 0 & 0 & 0 & 7 & 0 & 7 \\
F & 0 & 0 & 2 & 0 & 0 & 0 & 2 \\
G & 0 & 0 & 3 & 0 & 0 & 0 & 3 \\
H & 1 & 2 & 0 & 0 & 0 & 0 & 8 \\
Ungrouped & 0 & 0 & 7 & 1 & 0 & 0 & \\
strains & & 11 & 16 & 10 & 7 & 3 & 186 \\
$\quad$ Total & 139 & 11 & & & &
\end{tabular}


Table 5. Concordance of the number of strains common to the clusters formed by the principal components analysis and Clustan analysis using 32 and 41 tests respectively

\begin{tabular}{lrrrrrrr} 
Clustan groups & \multicolumn{8}{c}{ PCA groupings using 32 tests } & Ungrouped & \\
$\begin{array}{c}\text { separating at } \\
77 \% \text { similarity }\end{array}$ & $\mathrm{K}$ & $\mathrm{L}$ & $\mathrm{M}$ & $\mathrm{N}$ & $\mathrm{O}$ & strains & Total \\
I & 139 & 0 & 0 & 0 & 0 & 1 & 140 \\
II & 0 & 11 & 0 & 0 & 0 & 2 & 13 \\
III & 0 & 0 & 16 & 0 & 0 & 0 & 16 \\
IV & 0 & 0 & 0 & 10 & 0 & 0 & 10 \\
V & 0 & 0 & 0 & 0 & 7 & 0 & 7 \\
$\quad$ Total & 139 & 11 & 16 & 10 & 7 & 3 & 186
\end{tabular}

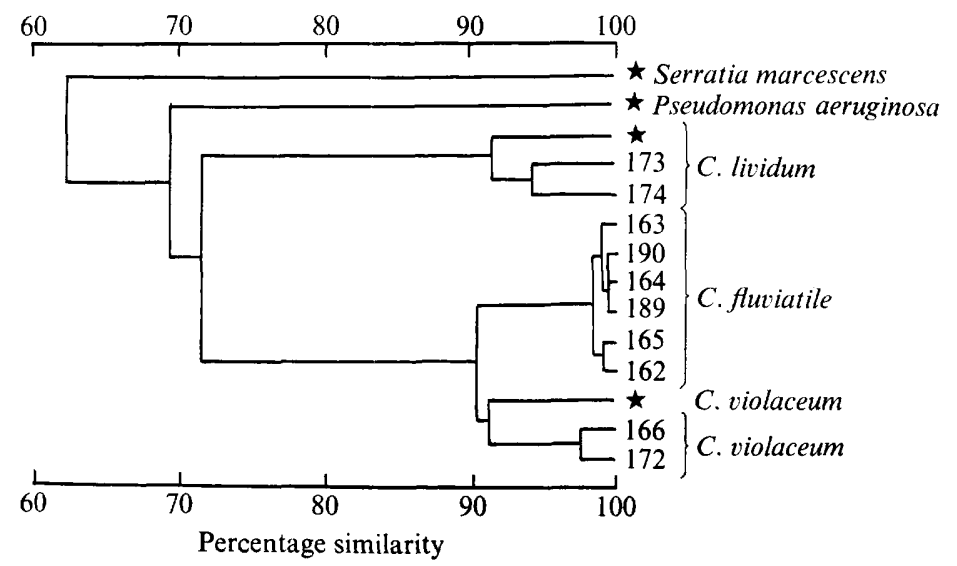

Fig. 4. Dendrogram based on a nearest neighbour analysis of the results of 59 observations on 10 strains of chromobacteria and 4 simulated strains (marked ${ }^{\star}$ ).

phosphatase; oxidase; turbidity from egg yolk; methylene blue reduction; acid from dulcitol, salicin, starch and xylose. Motility, pigment variability, growth on acetate and growth on 4NA were not included in this analysis.

A cluster analysis of these results as well as those for simulated strains is shown in Fig. 4. This dendrogram was based on a nearest neighbour analysis of the 59 characters, but all forms of cluster analysis computed gave essentially the same result, further confirming the closer relationship of the spreading isolates to $C$. violaceum than to $C$. lividum.

These studies, combined with the results of a GC determination on three strains of the spreading chromobacteria, lead us to suggest that they represent a distinct species for which the following description is given.

Chromobacterium fluviatile sp. nov.

(fluviatile, Latin, pertaining to the river.)

Gram-negative, round-ended rods 3 to $3.5 \times 0.7 \mu \mathrm{m}$, single and in short chains; occasionally elongated forms may be observed. Motile with a single polar flagellum and one or more lateral flagella.

Growth on solid media: pale violet, very thin, slightly roughened, spreading, irregular colonies 5 to $10 \mathrm{~mm}$ in diameter (isolated colonies on nutrient agar containing a quarter of the normal concentration of nutrients may reach 5 to $6 \mathrm{~cm}$ ). Colonies are often difficult to 
see, butyrous in consistency, readily emulsifiable in water and do not smell of ammonium cyanide. Growth in nutrient broth is moderate after $24 \mathrm{~h}$ at $25^{\circ} \mathrm{C}$, producing uniform turbidity and usually no pellicle. The pigment is spectroscopically indistinguishable from violacein.

Catalase, oxidase and phosphatase positive, capable of anaerobic growth and metabolizing glucose fermentatively. In Hugh and Leifson's medium acid is produced, without gas, from fructose, mannose, glucose, maltose and trehalose, but not from arabinose, xylose, galactose, cellobiose, lactose, sucrose, salicin, dulcitol, mannitol, sorbitol or inositol. A weak acid reaction is given by some isolates from glycerol in the same medium. Grows slowly on citrate, if at all. Casein and gelatin are both hydrolysed. Produces turbidity from egg yolk but only immediately beneath the colony. Weak haemolysis on goat blood agar. Nitrate, but not nitrite, is reduced without gas production. Methylene blue is reduced.

Reducing substances are produced by some strains from gluconate, but this reaction requires further study.

The following tests are negative: aesculin hydrolysis, starch hydrolysis, ornithine, arginine and lysine decarboxylases, malonate utilization and phenylalanine deamination, HCN and $\mathrm{H}_{2} \mathrm{~S}$ production, indole, urease and acetoin production. Grows best at $25{ }^{\circ} \mathrm{C}$ and able to grow at $4{ }^{\circ} \mathrm{C}$ but not at $37^{\circ} \mathrm{C}$. Strains survive for extended periods in dilute peptone water when stored at $4{ }^{\circ} \mathrm{C}$.

Isolated from river water. The GC ratio for three strains is 50.0 to $52.0 \mathrm{~mol} \%\left(T_{m}\right)$. Strains 165, 189 and 190 have been deposited with the National Collection of Type Cultures as no. 11159 (type strain), 11160 and 11161 respectively.

\section{DISCUSSION}

A number of authors have described violacein-producing Gram-negative rods which cannot be satisfactorily classified as strains of either of the currently accepted species of Chromobacterium. Hamilton \& Austin (1967) isolated a purple marine organism which they called $C$. marinum. This organism was considered to be very similar to the marine violaceinproducing isolates described by Gauthier $(1976 a)$. The low \% GC composition of the DNA of these latter strains, as well as a number of other characteristics, led Gauthier to place his isolates in the genus Alteromonas, described by Baumann et al. (1972), as A.luteo-violaceus. One of the characters commented on by Gauthier (1976a) as distinguishing members of the genus Chromobacterium from the marine isolates was the oxidase reaction which he reported as negative for the two species of Chromobacterium. Certainly members of the genus used to be considered oxidase-negative, but they are now recognized to be oxidasepositive (Bascomb et al., 1973; Sneath, 1974). The problem arises from the difficulty of carrying out the test in the presence of the intense purple pigments. However, Sivendra et al. (1975) demonstrated that non-pigmented strains of $C$. violaceum are strongly oxidasepositive, and they were able to confirm that pigmented strains of $C$. violaceum are also oxidase-positive, as were all strains of chromobacteria tested by us.

The low \% GC composition (41) and the absence of lateral flagella in the strains described by Gauthier (1976a) are good reasons for removing them from the genus Chromobacterium despite their ability to produce violacein. Indeed the production of a particular metabolite, or group of metabolites, should not be given undue weight in the taxonomy of micro-organisms. Interestingly, Gauthier $(1976 b)$ has also described a marine isolate which produces prodigiosin and which is considered to be a species of Alteromonas (A. rubra).

The \% GC of Chromobacterium fluviatile (50 to 52) is lower than the range presently accepted for Chromobacterium (63 to 77) and is within the range for Alteromonas (43 to 55) as modified by Lee, Gibson \& Shewan (1977). However the fermentative metabolism of all strains of spreading chromobacteria studied, coupled with the observation of lateral flagella, leads us to retain these strains in the genus Chromobacterium. This, however, is a matter of 
convenience and formally requires the description of the genus to be modified to allow inclusion of organisms with a \% GC content of their DNA as low as 50 .

The characterization and description of a wider range of distinctive species in the genus Chromobacterium may eventually help to resolve some of the problems concerning their relationship to each other and to other Gram-negative, oxidase-positive rods.

We thank Dr T. N. Bryant for considerable assistance with the computer analysis, D. Buist for assistance in obtaining ultraviolet and visible absorption spectra and the Natural Environment Research Council for the award of a studentship to C.R. It is a particular pleasure to thank Dr D. M. Gibson and his colleagues of the Torry Research Station for the determination of the \% GC composition of the DNA for three strains.

\section{REFERENCES}

Bascomb, S., Lapage, S. P., CuRtis, M. A. \& WILLCOX, W. R. (1973). Identification of bacteria by computer: identification of reference strains. Journal of General Microbiology 77, 291-315.

Baumann, L., Baumann, M., Mandel, M. \& Allen, R. A. (1972). Taxonomy of aerobic marine eubacteria. Journal of Bacteriology 110, 402-429.

Bernaerts, M. \& De Ley, J. (1971). 2,5-Diketogluconate formation by Chromobacterium. Antonie van Leeuwenhoek 37, 185-195.

Breed, R. S., Murray, E. G. D. \& SMith, N. R. (1957). Bergey's Manual of Determinative Bacteriology, 7th edn, p. 294. Baltimore: Williams \& Wilkins.

ConN, H. J. (1938). Taxonomic relationships of certain non-sporing rods in soil. Journal of Bacteriology 36, 320-321.

ConN, H. J. \& Elrod, R. P. (1947). Concerning flagellation and motility. Journal of Bacteriology 54, 681-687.

Cowan, S. T. \& Steel, K. J. (1965). Manual for the Identification of Medical Bacteria. Cambridge: Cambridge University Press.

GAUTHIER, M. J. (1976a). Morphological, physiological and biochemical characteristics of some violet-pigmented bacteria isolated from seawater. Canadian Journal of Microbiology 22, 138149.

GAUTHIER, M. J. (1976b). Alteromonas rubra sp. nov., a new marine antibiotic-producing bacterium. International Journal of Systematic Bacteriology 26, 459-466.

Gauthier, M. J., Shewan, J. M., Gibson, D. M. \& LEE, J. V. (1975). Taxonomic position and seasonal variations in marine neritic environment of some Gram-negative antibiotic-producing bacteria. Journal of General Microbiology 87, 211-218.

Hamilton, R. D. \& Austin, K. E. (1967). Physiological and cultural characteristics of Chromobacterium marinum sp. n. Antonie van Leeuwenhoek 33, 257-264.

Heberlein, G. T., De Ley, J. \& Tijtgat, R. (1967). DNA homology and taxonomy of Agrobacterium, Rhizobium and Chromobacterium. Journal of Bacteriology 54, 681-687.

Hugh, R. \& LeIFson, E. (1953). The taxonomic significance of fermentative versus oxidative metabolism of carbohydrates by various Gram negative bacteria. Journal of Bacteriology 66, 24-26.
Johnson, E. A. \& Beer, R. J. S. (1971). Violacein. In UV Atlas of Organic Compounds, vol. V, spectrum no. J8/2. Edited by H. H. Perkampus, I. Sandeman and C. J. Timmons. London: Butterworths.

Kovacs, N. (1956). Identification of Pseudomonas pyocyanea by the oxidase reaction. Nature, London 178, 703.

Lee, J. V., Gibson, D. M. \& Shewan, J. M. (1977). A numerical taxonomic study of some Pseudomonas-like marine bacteria. Journal of General Microbiology 98, 439-451.

LEIFSON, E. (1956). Morphological and physiological characteristics of the genus Chromobacterium. Journal of Bacteriology 71, 393-400.

MARChal, J. G. \& LASSEUR-ChaRPIOT, M. L. (1970). Study of the relationship between two chromogenic bacteria, Serratia marcescens and Chromobacterium violaceum. Travaux du Laboratoire de microbiologie de la Faculté de pharmacie de Nancy 20, 97-101.

Moffett, M. L. \& Colwell, R. R. (1968). Adansonian analysis of the Rhizobiaceae. Journal of General Microbiology 51, 245-266.

NorRIS, J. R. \& SwaIN, H. (1971). Staining bacteria. Methods in Microbiology 5A, 105-134.

O'Meara, R. A. Q. (1931). A simple, delicate and rapid method of detecting the formation of acetylmethyl carbinol by bacteria fermenting carbohydrates. Journal of Pathology and Bacteriology 34, 401-406.

Ryall, C. \& Moss, M. O. (1975). Selective media for the enumeration of Chromobacterium spp. in soil and water. Journal of Applied Bacteriology 38, 53-59.

SAKAZAKI, R. (1974). Serratia Bizio 1823. In Bergey's Manual of Determinative Bacteriology, 8th edn, p. 326. Edited by R. E. Buchanan and N. E. Gibbons. Baltimore: Williams \& Wilkins.

Shaw, C. \& Clarke, P. H. (1955). Biochemical classification of Proteus and Providence cultures. Journal of General Microbiology 13, 155-161.

SivendRA, R., Lo, H. S. \& Lim, K. T. (1975). Identification of Chromobacterium violaceum: pigmented and non-pigmented strains. Journal of General Microbiology 90, 21-31.

SNEATH, P. H. A. (1956a). Cultural and biochemical characteristics of the genus Chromobacterium. Journal of General Microbiology 15, 70-98. 
SNeATh, P. H. A. (1956b). The change from polar to peritrichous flagellation in Chromobacterium spp. Journal of General Microbiology 15, 99-105.

SNeATH, P. H. A. (1957). The application of computers to taxonomy. Journal of General Microbiology 17, 201-226.

SNeATH, P. H. A. (1960). A study of the bacterial genus Chromobacterium. Iowa State Journal of Science 34, 243-500.

SNEATH, P. H. A. (1966). Identification methods applied to Chromobacterium. In Identification Methods for Microbiologists, Part A, pp. 15-20. Edited by B. M. Gibbs and F. A. Skinner. London: Academic Press.

Sneath, P. H. A. (1972). Computer taxonomy. Methods in Microbiology 7A, 29-98.

SNEATH, P. H. A. (1974). Chromobacterium Bergonzini 1881. In Bergey's Manual of Determinative Bacteriology, 8th edn, pp. 354-357. Edited by R. E. Buchanan and N. E. Gibbons. Baltimore: Williams \& Wilkins.
Snell, J. J. S. \& Lapage, S. P. (1973). Carbon source utilization tests as an aid to the classification of non-fermenting Gram-negative bacteria. Journal of General Microbiology 74, 9-20.

SoKAL, R. R. \& Michener, C. D. (1958). A statistical method for evaluating systematic relationships. Kansas University Science Bulletin 38, 1409-1438.

THORNLEY, M. J. (1960). The differentiation of Pseudomonas from other Gram-negative bacteria on the basis of arginine metabolism. Journal of Applied Bacteriology 23, 37-52.

WaHlstedt, W. C. \& Davis, J. C. (1968). Fortran IV program for computation and display of principal components. Computer Contribution 21, State Geological Survey, University of Kansas, Lawrence, U.S.A.

WishaRT, D. (1969). Fortran II programs for 8 methods of cluster analysis. Computer Contribution 38, State Geological Survey, University of Kansas, Lawrence, U.S.A. 